\title{
Peranan Tokoh Dalam Tata Ruang Permukiman Masa Mataram Islam Dari Situs Potorono
}

\author{
Abdul Choliq Nawawi
}

Keywords: classification, settlement, Hindu, Yogyakarta, distribution, artifact

\section{How to Cite:}

Nawawi, A. C. Peranan Tokoh Dalam Tata Ruang Permukiman Masa Mataram Islam Dari Situs Potorono. Berkala Arkeologi, 15(3), 199-207. https://doi.org/10.30883/iba.v15i3.695

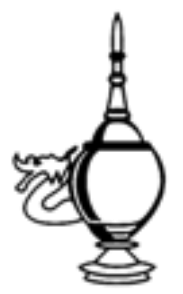

\section{Berkala Arkeologi}

https://berkalaarkeologi.kemdikbud.go.id/

Volume 15 No. 3, 1995, 199-207

DOI: 10.30883 /jba.v15i3.695

\section{c) (1) 8 (2)}

This work is licensed under a Creative Commons Attribution-NonCommercialShareAlike 4.0 International License. 


\title{
PERANAN TOKOH DALAM TATA RUANG PERMUKIMAN MASA MATARAM ISLAM DARI SITUS POTORONO
}

\author{
Abdul Choliq Nawawi \\ (Balai Arkeologi Yogyakarta)
}

\section{Latar Belakang Masalah}

Makalah ini didasarkan pada pernyataan Knebel, dalam artikel berjudul Beschrijving van Archaeologische Verzamling te Djogdjakarta, ROC,1902:123 yang menyatakan bahwa situs Potorono pernah ditemukan sebuah makara (Bosch, FDK., 1918:31).

Secara administratif situs Potorono terletak di Desa Potorono, Kecamatan Banguntapan, Kabupaten Bantul Propinsi Daerah Istimewa Yogyakarta. Secara astronomis terletak $3^{0} 37^{\prime 2} 2$ " BT dan 709'34" LS, meridian Jakarta (Topografi Yogyakarta, helai $47 / X 11 /$ skala 1 : 50.000 ).

Data arkeologis yang ditemukan di situs ini meliputi artefak, sumur kuna, kuburan masa Islam, struktur bangunan dan toponim. Berikut akan diuraikan peninggalan arkeologis tersebut.

1. Dari Dusun Salakan, Desa Potorono ditemukan Kuburan Kiai Sambuda dan Nyai Sambuda. Temuan serta berupa 4 buah fragmen keramik Cina, sebuah lingga dan yoni semu, struktur bata kuna, dan sebuah kotak batu bertutup

2. Kampung Potorono Kidul, Dusun Potorono, Desa Potorono terdapat kompleks kuburan 'Sampuma Sasanalaya' merupakan kuburan Kiai Gajahdelima. Selain itu ditemukan 2 buah batu persegi, 2 buah fragmen keramik Cina. Kampung. Potorono Lor ditemukan Kuburan Kiai Macanwalad dan sebuah sumur kuna, dengan temuan serta berupa 2 buah fragmen keramik Cina.

3. Dusun Prandanan (Prangwedanan), Desa Potorono, ditemukan kuburan Gusti Pangeran Aryo Prangwedono, Gusti Nerangkusumo, dan Gusti Penumping Panongsong. Di samping itu ditemukan 5 buah umpak batu persegi, sebuah sumur kuna,

4. Dusun Mayungan, Desa Potorono, ditemukan 16 buah batu persegi, 4 buah batu persegi berlubang, 2 buah fragmen keramik Cina dan 3 buah fragmen keramik Eropa, 8 buah batu persegi berpelipit membujur dari utara ke selatan, 1 buah kemuncak dari batu andesit, sebuah kalamakara dari batu kersikan, dan 4 buah batu persegi berlubang.

5. Dusun Mintoragan, Desa Potorono terdapat kompleks kuburan Kiai Mintorogo, dengan temuan serta sebuah fragmen keramik Cina.

6. Dusun Ngelo, Desa Potorono, ditemukan 3 buah sumur kuna, struktur bata, dan gumuk balekambang, dengan temuan serta berupa sebuah fragmen keramik Cina,

7. Dusun Nglaren, Desa Potorono, ditemukan sebuah sumur kuna, sebuah fragmen keramik Cina.

8. Dusun Mertosanan Kulon, Desa Potorono, ditemukan sebuah yoni dari batu andesit dan gumuk Mbah Jagarangin, temuan serta berupa sebuah fragmen keramik Cina, sebuah batu persegi dengan tonjolan bulat di tengahnya

9. Dusun Priyan, Desa Potorono, ditemukan 6 buah umpak batu bulat dan 2 buah umpak batu persegi, batu persegi.

10. Dusun Banjardadap, Desa Potorono, ditemukan 2 buah sumur kuna dengan temuan serta berupa 9 buah fragmen keramik Cina, 5 buah fragmen keramik Cina.

11.Selatan kuburan Panembahan Sampang, di Dusun Balong Lor, Desa potorono, ditemukan epitap berhuruf Arab terdiri dari 2 baris pada nisan kaki sisi luar dan 1 baris pada nisan kepala sisi luar. Selain itu ditemukan epitap berhurúf Jawa baru pada nisan kepala sisi dalam terdiri atas 4 dan pada nisan kaki sisi dalam terdiri atas 3 baris. Selain itu ditemukan sebuah sumur kuna, dengan temuan serta berupa 3 buah fragmen keramik Cina.

Kuburan Kanoman di selatan kuburan Panembahan Sampang, ditemukan sebuah kuburan yang tidak diketahui namanya oleh penduduk setempat, sedangkan temuan serta berupa 2 buah fragmen keramik Cina.

Istilah peranan dalam makalah ını adalah pimpinan terutama saat terjadinya suatu peris-tiwa (Poerwadarmintab, 1976:735). Sedangkan tokoh (achievement) yang dimaksud adalah ja-batan yang memiliki rencana untuk memperoleh fasilitas pendidikan dalam mengambil sutu kepu-tusan secara pribadi dan oleh pribadi itu sendiri (Durost, Walter N., et.al., 1978:104).

Bentuk pemukiman skala mikro, dikenal dengan sebutan space (ruang). Secara umum, pengertian space (ruang) merupakan tanda pengaturan: luas dan besar, bentuk (model), keadaan, jarak dan arah yang merupakan perubahan jenıs atau ragam. Ruang adalah kajian bentuk daiam geometri tentang barang-barang yang luas dan besarnya tidak dibatasi oleh waktu. Sebagian dari para pakar ilmu pengetahuan dan filosof Barat (Descartes, Newton, Samuel Alexander, dan lainlain) telah mempertimbangkan bahwa ruang 
secara objektif relatif sebagai tanda cap yang sah (Williams, Donald, C.,1976:353).

Dari pemyataan tersebut di atas, dapat dirumuskan hal-hal sebagai berikut:

1. Bagaimana keadaan tata ruang permukiman situs Potorono itu sebelum tokoh-tokoh dinasti Mataram Islam berperan?

2. Mengapa tokoh-tokoh utama masa Mataram Islam tersebut setelah wafat jenazahnya dikebumikan di situs Potorono?

Adapun metode yang digunakan untuk menyoroti masalah peranan tokoh dalam tata ruang permukiman masa Mataram Islam di situs Potorono, adalah tipe penelitian deskriptif dengan mengikuti pola penalaran induktif. Tipe penelitian deskriptif.adalah penelitian dengan memberikan gambaran lengkap tentang hal-hal yang diteliti dengan menjawab pertanyaan apa, dimana, dan kapan, sehingga dapat menemukan fakta atau gejala.

Kegiatan untuk mencapai deskripsi yang baik harus diperhitungkan kualitas data yang ber-kaitan dengan cara pencuplikan, alat ukur, dan penentuan statistik deskripsinya. Perangkat analisisnya meliputi: kategorisasi, klasifikasi, tipologi, penghitungan, penjumlahan, dan sebagainya. Sedangkan yang dimaksud dengan pola penalaran induktif yaitu pola penalaran yang bertitik tolak dari pengamatan hingga penyimpulan, bahkan sampai terbentuknya model atau teori (Tanudirjo, 1992:2. $3)$.

\section{Data dan Pembahasan}

Nama Potorono mengacu pada keberadaan sosial budaya Hinduistik. Hal tersebut disebab-kan secara ethimólogis, Potorono dalam bahasa Jawa Kuna Patarana diserap dari bahasa Prakrta Pattharana dan dari bahasa Sanskrta Prasatarana yang berarti balai-balai; tempat duduk; bantal untuk upacara atau tikar untuk tempat duduk (Zoetmulder, PJ, 1982:1319).Nama Potorono sampai sekarang masih tetap dilestarikan.

Kondisi situs Potorono terletak di tanah datar pantai selatan Jawa Tengah. Tanah datar pantai selatan memiliki lebar $\pm 10-25 \mathrm{~km}$. Pantai selatan menunjukkan perbedaan tajam dengan pantaipantai karang bagian selatan Jawa Barat dan Jawa Timur, yang terletak $\pm 10 \mathrm{~m}$ di atas permukaan laut. Lahan sekitar pantai selatan Jawa Tengah ini relatif subur.

Permukiman kuna masa Mataram Islam di Potorono memiliki lahan yang subur dan cocok sebagai lahan agraris. Secara tradisional situs Potorono termasuk dalam lingkup sosial budaya Mataram di propinsi Daerah Istimewa Yogyakarta Oleh karena itu patut kiranya lahan situs Potoro- no dijadikan tempat permukiman secara berkelanjutan.

Kajian pola permukiman meliputi hubungan antar lapisan sosial. Pengertian tersebut secara luas dapat dijabarkan berikut. Neraca inti (core scale), karakter garis keliling (periphery), dan penyimpangan (perbedaan) pada pola permukiman antara sistem ruang di lapisan bawah. Pola-pola permukiman pada lapisan bawah tersebut, dapat dibedakan dari bentuk kajian yang meliputi tata ruang itu sendiri. Dari bentuk kajian ini, akan diperoleh beberapa gagasan mengenai kajian tata ruang pada lapisan inti (pusat) maupun lapisan garis keliling (periphery) dan akan diketahui pula situasi tata ruang yang terisolasi. Kajian mengenai tata ruang periphery sulit untuk diteliti dan ditetapkan keadaan yang sebenarnya. Berdasarkan himpunan data permukiman, kiranya dapat miembantu mengetahui sistem kekuasaan pada masa itu dan darimana lapisan sosial tersebut terbentuk. Perlunya keahlian dalam mencermati artefak, kuburan-kuburan yang dipandang keramat dan arsitektur monumental pada lapisan sosial di garis keliling (periphery) suatu wilayah. Selain itu produksi lokal sering juga dijumpai sebagai dasar mata pencaharian masyarakat lapisan bawah (Paynter, Robert, $1982: 4-5$ ).

Tinggalan sosial budaya situs Potorono meliputi: artefak, ekofak, sumur kuna, kuburan kuna. struktur bangunan kuna, dan toponim. Khusus artefak berupa fragmen keramik Cina diperlukan kajian kronologis yang didasarkan atas buku Ireneus Laszlo Legeza berjudul: Malcolm MacDonald Collection of Chinese Ceramics, terbitan London Oxford University Press, tahun 1872.

Berdasarkan hasil pengamatan arkeologis $d t$ lapangan, maka kategorisasi permukiman kuna di Potorono dibagi menjadi 5 kelompok (Cluster) yaitu: Potorono, Mintoragan, Mertosanan, Banjardadap, dan Balong. Berikut akan diuraikan masing-masing kelompok permukiman tersebut.

Kelompok permukiman Potorono terdiri dari situs-situs di Dusun: Salakan, Botokan, Potorono Kidul, Potorono Lor, Prandanan (=Prangwedanan), dan Mayungan.

\section{Dusun Salakan}

Situs kuburan Kiai Sambuda dan Nyai Sambuda di Dusun Salakan. Nisan dan jiratnya tersusun dari batu persegi polos. Kuburan ini terletak di bawah rumpun bambu. Keadaan kuburan ini tidak terawat dan menurut informasi dari penduduk setempat ahli wạrisnya sudah tidak ada lagi. Oieh penduduk setempat Kiai Sambuda dan Nyai Sambuda dianggap sebagai cikal bakal masyarakat Dusun Salakan. Temuan serta berupa 4 buah fragmen keramik Cina yang terdiri dari: 
sebuah fragmen badan dan sebuah kaki mangkuk dari daerah Lung-Ch'uan, propinsi Chekiang, dinasti Sung abad XII-XIII $M_{i}$ sebuah fragmen bibir mangkuk dari daerah Ching-te-chen, propinsi Kiangsi, pada masa pemerintahan Hsuan-te (1426-1435 M) dari dinasti Ming; dan sebuah fragmen karinasi piring dari Cina utara pada masa dinasti T'ang abad VII-IX M.

\section{Dusun Potorono}

Situs Botokan, terletak di tengah lahan persawahan tempat kegiatan pembakaran bata. Pada galian tanah tempat pembuatan bata ini ditemukan sebuah lingga-yoni semu. Lingga semunya dari batu kersikan yang berukuran tinggi $32 \mathrm{~cm}$. Lingga bagian atas berbentuk bulat tinggi $17 \mathrm{~cm}$ dan garis tengah $15 \mathrm{~cm}$. Lingga bagian bawah berbentuk bujur sangkar, masing-masing sisinya berukuran $15 \mathrm{~cm}$. Sedangkan yoni semunya dari bahan batu putih. Yoni semu berbentuk bujur sangkar ganda berukuran masing-masing sisi 58 $\mathrm{cm}$, sisi atas $42 \mathrm{~cm}$, lebar sisi bawah $20 \mathrm{~cm}$ dan lebar sisi atas $21 \mathrm{~cm}$. Lisban yoni semu berukuran $7 \mathrm{~cm}$ dan lebar antara garis tepi sisi dalam lisban yoni dengan lubang yoni tempat menancapnya lingga sekitar $8 \mathrm{~cm}$, tinggi yoni $41 \mathrm{~cm}$. Selain itu ditemukan juga sebuah wadah kotak batu tertutup dari bahan batu putih. Tinggi wadah kotak batu bertutup ini seluruhnya $32 \mathrm{~cm}$ dan lebar masing-masing sisinya $321 / 2 \mathrm{~cm}$. Panjang lubang wadahnya $20 \mathrm{~cm}$, lebar $15 \mathrm{~cm}$, dan kedalamannya $10 \mathrm{~cm}$. Di dalam wadah ini terdapat serbuk menyerupai pasir dan 2 buah peripih dari lembaran emas dan perunggu masing-masing berukwaran panjang $3 \mathrm{~cm}$ dan lebar $2 \mathrm{~cm}$. Pada lembaran peripih emas ini terdapat inskripsi berhuruf Jawa Kuna, dan berdasarkan hasil bacaan M.M. Sukarto Kartoatmodjo berbunyi swah atau suh yang berarti alam semesta. Selain itu juga ditemukan 2 buah batu persegi, masing-masing berukuran panjang $42 \mathrm{~cm}$, lebar $41 \mathrm{~cm}$, dan tinggi $20 \mathrm{~cm}$. Temuan serta berupa sebuah fragmen bibir piring keramik Cina dari daerah Ching-techen, propinsi Kiangsi, pada masa pemerintahan Wanli (1573-1619) dari dinasti Ming.

Toponim Botokan berasal dari bahasa Jawa Baru, yaitu Botok dan memperoleh akhiran an. Kata ini diserap dari bahasa Jawa Kuna Betek yang berarti juru masak (Mardiwarsito,L., 1981:114). Jadi Botokan berarti tempat juru masak. Sekitar 350 meter di sebelah utara situs ini terdapat situs kuburan Kiai Gajahdelimo yang terletak da-lam kompleks kuburan Sampurna Sasanalaya di kampung Potorono Kidul, Dusun Potorono, Desa Potorono. Bentuk jirat dan nisan kuburan ini berbeda dengan jirat dan nisan kuburan lain yang umurnya relatif lebih muda. Jirat dan nisan kuburan Kiai Gajahdelimo berbahan batu putih. Kondisi fisik jirat dan nisan kuburan sudah aus. Menurut informasi penduduk setempat, Kiai Gajahdelimo ini mantan seorang demang pada masa pemerintahan Panèmbahan Senopati Ing Alogo kerajaan Mataram Islam. Panembahan Senopati ing Alogo memerintah kesultanan Mataram Islam pada tahun 1575 M (Sutjipto,FA,ed, 1977: 1)

Di kampung Potorono Kidul ditemukan 2 buah batu persegi. Masing-masing berukuran panjang $92 \mathrm{~cm}$ dan $77 \mathrm{~cm}$, lebar seutuhnya sama yaitu 30 $\mathrm{cm}$, dan lekukan $10 \mathrm{~cm}$ dan $20 \mathrm{~cm}$, serta tinggi masing-masing $30 \mathrm{~cm}$. Batu persegi ini tampaknya difungsikan sebagai penyekat, dan temuan serta berupa 2 buah fragmen keramik Cina terdir dari: sebuah fragmen piring Cina bagian bibir dari daerah Chun-chou, propinsi Honan, pada masa dinasti Sung abad XII-XIII $M$, sebuah fragmen mangkuk bagian badan dari daerah Chun-chou, propinsi Honan, pada masa dinasti Sung abad XIIXIII M.

Kampung Potorono Lor, ditemukan situs kuburan Kiai Macanwalad. Kuburan ini sudah dipugar total oleh seseorang yang telah tercapai nazar dan kaulnya. Menurut informasi penduduk setempat, Kiai Macanwalad berasal dari majapahit, keturunan Adipati Blambangan. Di kampung ini juga ditemukan sebuah sumur kuna. Ciri kekunaannya berupa 3 buah batu persegi. Temuan serta berupa 2 buah fragmen keramik Cina terdiri dari: sebuah fragmen karinasi stoples dari daerah Yung-lo, propinsi Kiangsi, masa dinasti Sung abad XII-XIII $M$; sebuah fragmen bibir mangkuk dari daerah Ching-te-chen, propinsi Kiangsi, pada masa pemerintahan Ch'ien-lung (1736-1795 M) dari dinasti Ch'ing.

\section{Dusun Prandanan}

Di Dusun Prandanan (=Prangwedanan), ditemukan kuburan: Gusti Pangeran Aryo Prangwedono, Gusti Nerangkusumo, dan Gusti Panumping Panongsong. Kuburan ini terletak di kompleks kuburan umum. Dusun ini ada yang menyebut Prandanan atau Prangwedanan. Nama Prandanan berasal dari bahasa Sanskrta pradhana memperoleh partikel sandi dalam $n$ dan arealis en. sehingga menjadi pra+ $n+d h a n a+e n$ yang ber-arti terkemuka, terpenting, sesuatu yang di depan (Mardiwarsiti,L, 1981:429). Sedangkan nama Prangwedanan, menurut informasi penduduk setempat dimaksud untuk mengabadikan nama almarhum Gusti Pangeran Arya Prangwedono.

Babad Magkubumi menyebutkan ketika Gubernur Jenderal Marsekal Daendels berada di Se- 
marang, ia mengirimkan dua pucuk surat ke Surakarta dan Yogyakarta. Isi surat memberitakan ia akan berkeliling Jawa dan mengerahkan pra-jurit kompeni sejumlah 7000 orang. Selanjutnya Kanjeng Gusti Pangeran Adipati Prabu Prangwedono diharapkan hadir di Semarang, sebab akan diberi anugerah bintang dan diangkat menjadi putra bungsu Gubernur Jenderal Marsekal Daendels dan terdaftar sebagai prajurit kompeni Belanda (Sastronaryatmo,Moeljono, 1981:170-1).

Nama Gusti Nerangkusumo seperti yang diinformasikan penduduk setempat, kiranya tidak disebutkan dalam Babad Mangir jilid 1 dan 2. Sedangkan nama Gusti Panumping Panongsong menduduki jabatan tertinggi dalam prajurit $\mathrm{Pa}$ numping. Babad tersebut menyatakan semua prajurit Mataram berbaris di alun-alun. Barisan terdepan terdiri dari prajurit Numbakanyar, prajurit Sewu, prajurit Panumping, dan sebagainya (Balai Penelitian Bahasa Yogyakarta, 1980: 114). Jabatan Panumping adalah sebagai wedana jawi (wedana luar) yang mempunyai tempat kediaman di Kutagara wilayah Negara Agung (Sutjipto, FA,ed, 1977:4)

Temuan di Dusun Prandanan (Prangwedanan) adalah: 5 buah umpak batu persegi ( 4 buah berukuran: panjang bagian atas dan bawah 30 $\mathrm{cm}$, lebar bagian atas dan bawah $20 \mathrm{~cm}$, tebal bagian atas $61 / 2 \mathrm{~cm}$, dan tebal bagian bawah 5 $\mathrm{cm}$, serta tinggi badannya $8 \mathrm{~cm}$ dan sebuah umpak lainnya berukuran: panjang $28 \mathrm{~cm}$, lebar 28 $\mathrm{cm}$, dan tinggi $18 \mathrm{~cm}$ ), umpak ini berlubang buntu sebuah bergaris tengah $10 \mathrm{~cm}$; sebuah sumur kuna yang struktur cemplongnya dari bata kuna masia in situ.

\section{Dusun Mayungan}

Sekitar $300 \mathrm{~m}$ sebelah barat kompleks kuburan Prangwedanan ditemukan 16 buah batu persegi dan fitur struktur bata kuna dengan ukuran masing-masing:

1. panjang (p) $63 \mathrm{~cm}$, lebar (I) $42 \mathrm{~cm}$, dan tebal (tb) $15 \mathrm{~cm}$, bagian tengah terdapat lubang tembus bergaris tengah $18 \mathrm{~cm}$ dan kedalaman (d) $=$ tebal

2. p $42 \mathrm{~cm}, 128 \mathrm{~cm}$, dan th $12 \mathrm{~cm}$, bagian tengah terdapat sebuah lubang tembus bergaris tengah $14 \mathrm{~cm}$ dan $d=$ tb.

3. p $69 \mathrm{~cm}, 145 \mathrm{~cm}$, th $13 \mathrm{~cm}$, bagian tengah berlubang tembus 3 buah masing-masing bergaris tengah $121 / 2 \mathrm{~cm}$ dan $d=t b$.

4. polos, p $64 \mathrm{~cm}, \mid 43 \mathrm{~cm}$, dan tb $14 \mathrm{~cm}$.

5. berlubang tembus 1 buah. Ukuran $p 53 \mathrm{~cm}, 138$ $\mathrm{cm}$, dan tb $15 \mathrm{~cm}$. Garis tengah lubang tembusnya $17 \mathrm{~cm}$ dan $\mathrm{d}=\mathrm{tb}$.

6. polos, berukuran $\rho 68 \mathrm{~cm}, 139 \mathrm{~cm}$, tb $18 \mathrm{~cm}$.

7. polos, berukuran $p 79 \mathrm{~cm}, 141 \mathrm{~cm}$, tb $14 \mathrm{~cm}$.
8. polos, berukuran $p 71 \mathrm{~cm}, 132 \mathrm{~cm}$, tb $20 \mathrm{~cm}$.

9. berlubang tembus 1 buah, berukuran $p 64 \mathrm{~cm}$, I $43 \mathrm{~cm}$, tb $18 \mathrm{~cm}$. Garis tengah lubang tembusnya $18 \mathrm{~cm}, d=$ tb.

10. berlubang tembus 1 buah, berukuran $p 46 \mathrm{~cm}$, I $381 / 2 \mathrm{~cm}$, tb $13 \mathrm{~cm}$. Garis tengah lubang tembusnya $16 \mathrm{~cm}$ dan $\mathrm{d}=\mathrm{tb}$.

11. berlubang buntu 1 buah, berukuran panjang 56 $\mathrm{cm}$, lebar $39 \mathrm{~cm}$, dan tinggi $36 \mathrm{~cm}$. Garis tengah lubang buntunya $20 \mathrm{~cm}$ dan d $20 \mathrm{~cm}$.

12.terpendam dalam tanah. Ukuran yang kelihatan di permukaan tanah p $46 \mathrm{~cm}, 112 \mathrm{~cm}$, dan tinggi yang kelihatan $10 \mathrm{~cm}$.

13. polos, berukuran p $38 \mathrm{~cm}, 138 \mathrm{~cm}$, tb $9 \mathrm{~cm}$.

14. berlekuk dengan ukuran p $57 \mathrm{~cm}, 134 \mathrm{~cm}$, tb $18 \mathrm{~cm}$. Panjang lekukan $19 \mathrm{~cm}, 114 \mathrm{~cm}, d$ lekukan $=$ tb.

15. polos, berukuran $\mathrm{p} 73 \mathrm{~cm}, \mid 41 \mathrm{~cm}$, tinggi 35 $\mathrm{cm}$.

fitur struktur bata, 4 buah umpak batu persegi berlubang buntu sebuah masing-masing berukuran: p sisi luar bagian atas dan bawah $75 \mathrm{~cm}$, I sisi dalam bagian atas dekat lubang $53 \mathrm{~cm}$, tinggi 60 $\mathrm{cm}$, th lisban $12 \mathrm{~cm}$. Panjang dan lebar sisi-sisi lubangnya $25 \mathrm{~cm}$ dan d $25 \mathrm{~cm}$., 2 buah fragmen keramik Cina terdiri dari 2 buah fragmen bibir cangkir dari Ching-te-chen, propinsi Kiangsi, masa pemerintahan Yung-cheng (1723-1735 M) dinasti Ch'ing, 8 buah batu persegi berpelipit (di antara batu persegi berpelipit yang masih utuh dan terpanjang berukuran: p $57 \mathrm{~cm}, 124 \mathrm{~cm}$, tb tidak diketahui secara pasti karena tertanam di dalam tanah, sebuah kemuncak dari batu andesit berukuran tinggi $125 \mathrm{~cm}$, sebuah kalamakara dari batu kersikan, dan 4 buah umpak batu persegi berlubang buntu 1 buah. Masing-masing umpak batu berlubang buntu berukuran $p$ dan $175 \mathrm{~cm}$, tinggi $60 \mathrm{~cm}$, lisban $12 \mathrm{~cm}$, sisi-sisi lubang berukuran $22 \mathrm{~cm}$, dan d lubang $22 \mathrm{~cm}$.

Toponim Mayungan berasal dari kata oasar payung (ngoko), songsong (krama inggil). Informasi penduduk setempat nama kampung Mayungan dimaksudkan untuk mengabadikan nama Gusti Panumping Panongsong di kompleks kuburan Prandanan (Prangwedanan) yang terletak di timur Dusun Mayungan. Di samping itu Mayungan, menurut informasi penduduk merupakan lokasi permukiman abdi dalem keraton Mataram Islam yang bertugas membawa payung pada upacara kebesaran di kesultanan Yogyakarta Hadiningrat sejak masa pemerintahan Suitan $\mathrm{Ha}$ mengkubuwono!.

\section{Dusun Matoragan}

Dusun ini terietak sekitar $\uparrow 1 / 2 \mathrm{~km}$ timur Dusun Mayungan, ditemukan kompleks kuburan Mintoragan. Di kompleks kuburan ini terdapat 12 
buah kuburan yang dibatasi tembok keliling tanpa atap, berukuran $6 \times 7$ meter persegi dan pintu masuknya dari arah selatan. Kuburan ini berderet menjadi dua baris. Satu baris di bagian utara terdiri dari 5 buah kuburan dan di bagian selatan 7 buah kuburan. Kuburan nomor 2-5 di bagian utara, yaitu dari arah barat ke timur, pada nisannisannya terdapat epitap. Begitu juga pada kuburan nomor 6 di bagian selatan, yaitu pada jajaran baris paling barat. Secara vertikal 12 buah kuburan yang terletak dalam tembok keliling ini keadaannya relatif lebih tinggi dibandingkan dengan kuburan-kuburan yang terletak di luar tembok keliling tersebut

Epitap pada nisan kepala sisi dalam di kuburan nomor 2 ini berhuruf Jawa Baru terdiri dari 2 baris. Bunyi epitap ini sebagai berikut: Kiail cakrawedono ping 1, tanpa angka tahun. Sedang. kan epitap pada nisan kepala sisi dalam di kuburan nomor 3 berhuruf Jawa Baru juga terdiri dari 2 baris. Bunyi epitap ini sebagai berikut: Kiai / guru 'g 'mintorogo. Huruf (g) pada epitap ini da-pat mengacu pada angka 1 dan bermakna dari singkatan kata gendhing terkait dengan toponim watukempul. Dalam keraton Yogyakarta, terdapat jabatan abdi dalem gendhing yang bertugas membuat gamelan (Sutjipto,FA, 1977: 10)

Epitap pada nisan kepala sisi dalam kubur-an nomor 4 berhuruf Jawa Baru terdiri dari 3 ba-ris tanpa angka tahun. Epitap ini berbunyi: 116= 38=7M. Lu./cokrowedono "2"\%. Angka-angka yang tertulis pada epitap merupakan kode suatu rahasia dan singkatan huruf $M$ dan akronim Lu. Kode ini dari kata Mas dan Lurah. Dalam susunan birokrasi kesultanan Mataram Islam, jabatan lurah sebagai wakil dari seorang Demang (Ibid, 1977:5).

Epitap pada nisan kaki sisi luar kuburan nomor 5 berhuruf Jawa Baru terdiri dari 2 baris, tanpa angka tahun. Bunyi epitap: Mas /urah/cokrowedono/. Sedangkan epitap pada nisan kaki sisi luar kuburan nomor 6 berhuruf Jawa Baru terdiri dari 2 baris. Bunyi epitap: Den nganten /cokrowedonol. Temuan serta berupa sebuah fragmen bibir mangkuk dari Lung-ch'uan, propinsi Chekiang dinasti Sung abad XII-XIII M.

\section{Dusun Ngelo}

Sekitar $500 \mathrm{~m}$, sebelah barat kompleks kuburan Mintoragan ditemukan 3 buah sumur kuna, struktur bata dan gundukan tanah oleh penduduk setempat disebut gumuk balekambang. Temuan serta berupa sebuah fragmen dasar piring Cina dari Ching-te-chen, propinsi Kiangsi, masa pemerintahan Hung-chih (1488-1505 M) dinasti Ming.

\section{Dusun Ngiaren}

Di dusun ini ditemukan sebuah sumur kuna. Temuan serta berupa sebuah fragmen dasar mangkuk Cina dari daerah Lung-ch'uan masa dinasti Sung abad XII-XIII $M$; sebuah fragmen dasar mangkuk Cina, temuan semacam juga ditemu-kan di Dusun Kenalan, 50 m utara dusun ini.

\section{Dusun Mertosanan}

Di dusun ini ditemukan sebuah yoni dari andesit dan gundukan tanah oleh penduduk setempat disebut Gumuk Mbah Jagarangin. Temuan serta berupa sebuah fragmen dasar mangkuk Cina berasal dari Lung-Ch'uan, dinasti Sung abad XII-XIII $M$; sebuah umpak batu persegi dengan tonjolan bulat di tengah-tengahnya

\section{Dusun Priyan dan Dusun Geneng}

Di dusun ini ditemukan 6 buah umpak batu bulat dan 2 buah umpak batu persegi; sebuah batu persegi tertanam dekat pematang

Di Dusun Geneng ditemukan 2 buah sumur kuna, dengan temuan serta 9 buah fragmen keramik Cina terdiri dari: sebuah fragmen bibir stop-les Cina dari Chiu-yen, dekat Shao-hsing, propin-si Chekiang, masa pemerintahan the three kingdoms (San-Kuo) dari Enam Dinasti abad III-IV M. sebuah fragmen mangkuk Cina bagian dasar dari Cina utara, yaitu dari Hao-pi, propinsi Honan, dinasti Sung abad XII-XIII M; sebuah fragmen dasar mangkuk dari daerah Lung-ch'u-an, propinsi Chekiang, dinasti Sung abad XII-XIII M; sebuah fragmen dasar mangkuk dari propinsi Hopei, dinasti T'ang abad VIII-IX M; sebuah fragmen badan jotol produksi dinasti Chin atau masa awal sinast Yuan abad XIII M; sebuah fragmen bibir mangikuk produksi daerah Cheng-te-chen, propinsi Kiangs।. dinasti Hsuen-te (1426-1435 M) dan dinasti Ming: tiga buah fragmen bibir piring Cina produksi daerah Ching-te-chen, propinsi Kiangshi, pemerintahan Kiang-shi (1662-1722 M).

\section{Dusun Balong}

Di Dusun Balong Kidul ini ditemukan 5 buah fragmen ke-ramik Cina terdiri dari sebuah fragmen dasar mangkuk produksi daerah Lung-ch'uan, propinsi Chekiang, dinasti Sung abad XII-XIII $M_{\text {; }}$ sebuah fragmen piring dasar produksi daerah Ching-te-chen, propinsi Kiangsi, pemerintahan Ch'ien-lung (1736-1795 M) dinasti Ch'ing; sebuah fragmen dasar piring dari daerah Ching-te-chen. propinsi Kiangsi, dinasti Ming awal abad XVII M. sebuah fragmen dasar cangkir dari daerah Cina utara, di-nasti Tang abad VII-X $M_{i}$ sebuah fragmen kari-nasi stoples dari daerah LungCh'uan, propinsi Chekiang, dinasti Sung abad XIIXIII $M_{\text {; }}$ 
Dusun Baiong Lor, terdapat kompleks kuburan Pangeran Sampang, epitap berhuruf Arab terdiri dari 2 baris pada nisan kaki sisi luar dan 1 baris pada nisan kepala sisi luar. Epitap berhuruf Arab pada nisan kepala sisi luar berbunyi: Allah dan epitap pada nisan kaki sisi luar berbunyi: Muhammad. Sedangkan epitap pada nisan kepala sisi dalam berhuruf Jawa Baru terdiri dari 5 baris. Transliterasi epitap ini berbunyi:

Ha / U /
ingkang ajal /
mas ajeng nuriyadmi
tan........... (aus)
tanggal kaping : 3

Transliterasi epitap pada nisan kaki sisi dalam berbunyi:

\section{Wulan bessar ta- \\ hunne angkaning warsa \\ 1798}

Jirat dan nisan kuburan tersebut berbahan batu putih; epitap pada nisan kaki sisi luar, berhuruf Jawa Baru terdiri dari 7 baris. Transliterasi dan bunyi epitap tersebut menurut M.M. Sukarto Karto Atmodjo sebagai berikut.

Masa
1783
nyai
masupi
....... (belum tertaca) papa rata
ulah wahyu sawara

(belum terbaca)

Selaif itu ditemukan sebuah sumur kuna, dengan temuan serta berupa 3 buah fragmen keramik Cina terdiri dari: sebuah fragmen dasar mangkuk dari Cina selatan, pemerintahan Wan-li (15731619 M) dinasti Ming; sebuah fragmen dasar piring dari daerah Ching-te-chen, propinsi Kiangsi, pemerintahan Wan-li !1573-1619 M) dinasti Ming; sebuah fragmen badan mangkuk dari daerah Lung-ch'uan, propinsi Chekiang, dinasti Sung abad XII-XIII M.

Temuan penting lain di Dusun Balong Lor adalah kuburan Kanoman. Kuburan ini terietak sekitar $150 \mathrm{~m}$ di sebelah barat kompleks kuburan umum dekat kuburan Pangeran Sampang. Jirat dan nisan kuburan Kanoman tersebut dari bahan batu putih.

\section{Dusun Blado}

Di dusun ini terdapat sebuah kuburan yang tidak dikenali lagi namanya oleh penduduk setempat. Jirat dan nisan kuburan ini berbahan batu andesit. Temuan serta berupa 2 buah fragmen keramik Cina yang terdiri dari: sebuah fragmen bibir mangkuk dari daerah Cina selatan, akhir abad XVIII M dinasti Ch'ing; sebuah fragmen badan cangkir dari daerah Ching-te-chen, propinsi Kiangsi, pemerintahan Hsuan-te (1426-1435 M) dinasti Ming.

\section{Kesimpulan}

Berdasarkan banyaknya jumlah artefak tinggalan sosial budaya Hinduistik di kelompok permukiman Potorono, yaitu di situs Botokan, Potorono Kidul, Ptorono Lor, dan Mayungan sebagai pusat temuan tinggalan bangunan monumental semacam kuil Hinduistik, maka dapat disimpul-kan secara tentative (sementara) pada masa kla-sik. permukiman Potorono merupakan lahan tata ruang permukiman inti (core scale) dalam lapisan sosial budaya Hinduistik.

Sedangkan kelompok permukiman Mertosanan terdiri dari situs Kranginan, Geneng, dan Priyan, banyak ditemukan umpak-umpak batu bulat dan umpak-umpak batu persegi dan sebuah yoni dari batu andesit, merupakan lahan tata ruang permukiman dengan karakter garis keliling (penphery) dalam lapisan sosial budaya Hinduistik.

Kelompok permukiman Mintoragan, Banjardadap, dan Balong, dengan tinggalan benda-benda sosial budaya Hinduistiknya jarang ditemukan dapat disimpulkan kelompok permukiman lapis-an bawah yang terisolasi dari sosial budaya Hinduistik.

Berdasarkan banyaknya jumlah artefak sosial budaya Mataram Islam berupa kuburan tokoh/ pejabat di kelompok permukiman Potorono, yaitu di Prandanan dan Balong, maka dapat disimpulkan tradisional, kelompok permukiman Potorono dipandang memiliki banyak kekuatan magis oleh para pejabat di kesultanan Mataram Islam. Sedangkan kelompok permukiman Balong merupakan permukiman inti (core scale) bagi penguburan jenazah kerabat kesultanan Mataram Islam. Kelompok permukiman Mintoragan merupakan permukiman berkarakter garis keliling (periphery) Mataram Islam.

Kelompok permukiman Mertosanan dan Banjardadap merupakan permukiman terisolasi sosial budaya Mataram Islam.

\section{KEPUSTAKAAN}

Anonim, 1980, Babad Mangir 1 dan 2 Bahasa Indonesia, terbitan Departemen Pendidikan dan Kebudayaan, Proyek Penerbitan Buku Sastra Indonesia dan Daerah, Jakarta

Bemmelen,RW. van,1949, The Geology of Indonesia vol. IA, Genera! Geology of Indonesia 
and Adjecent Archipelagoes terbitan Government Printing Office, The Hague

Bosch,FDK, 1918, Rapporten van den Oudheidkundige Dienst in Nederland-Indie $\mathbf{9 1 5}$ Tweede Deel, Uitgegeven door het Bataviaasch Genootshap van Kunsten en Wetenschappen, terbitan Albrecht 6 Co. Welterreden, M. Nijhoff 's-Gravenhage.

Daud Aris Tanudirjo, 1992, Penelitian Arkeologi: Bahan Kajian daiam Diskusi tentang Penelitian Arkeologi Makalah Temu IImiah Rutin (TIR), Yogyakarta.

Durost, Walter N.et.al., 1978, The Encyclopedia Americana, International edition vol. I Danbury, Connecticut 06816.

Legeza, Ireneus Laszlo.,1972, Malcolm MacDonald Collection of Chinese Ceramics terbit-an London Oxford University Press, New York, Toronto.

Mardiwarsito,L., 1981. Kamus Jawa Kuna-Indonesia, terbitan Nusa Indah, Percetakan Arnoldus, Ende-Flores.

Paynter,Robert., 1982. Model of Spatial Inequality Settlement Patterns in Historical Archaelogy terbitan Academic Press (AP). New York, London.
Poerwadarminta, WJS, 1976.Kamus Umum Bahasa Indonesia Balai Pustaka, Jakarta

Sastronaryatmo,Moeljono, 1981. Babad Mangkubumi, Departemen Pendidikan dan Kebudayaan, Proyek Penerbitan Buku Sastra Indonesia dan Daerah, Jakarta.

Sutjipto,FA.ed.1977. SejarahNasional Indonesia IV: Indonesia dalam Abad XVIII dan XIX, Departemen Pendidikan dan Kebudayaan, Balai Pustaka, Jakarta.

Williams,Donald.C, 1978. The Encyclopedia Americana, International edition, terbitan Americana Corporation International Headquarters, vol. 25, Danbury, Connecticut 06816 .

Zoetmulder,PJ, Old 1982. Javanese-English Dictionary, jilid II, terbitan 's-Gravenhage-Martinus Nijhoff. 
Tabel : Sub-assemblage, assemblage, dan populasi temuan benda arkeologi di situs Potorono, Kecamatan Banguntapan, Kabupaten Bantul.

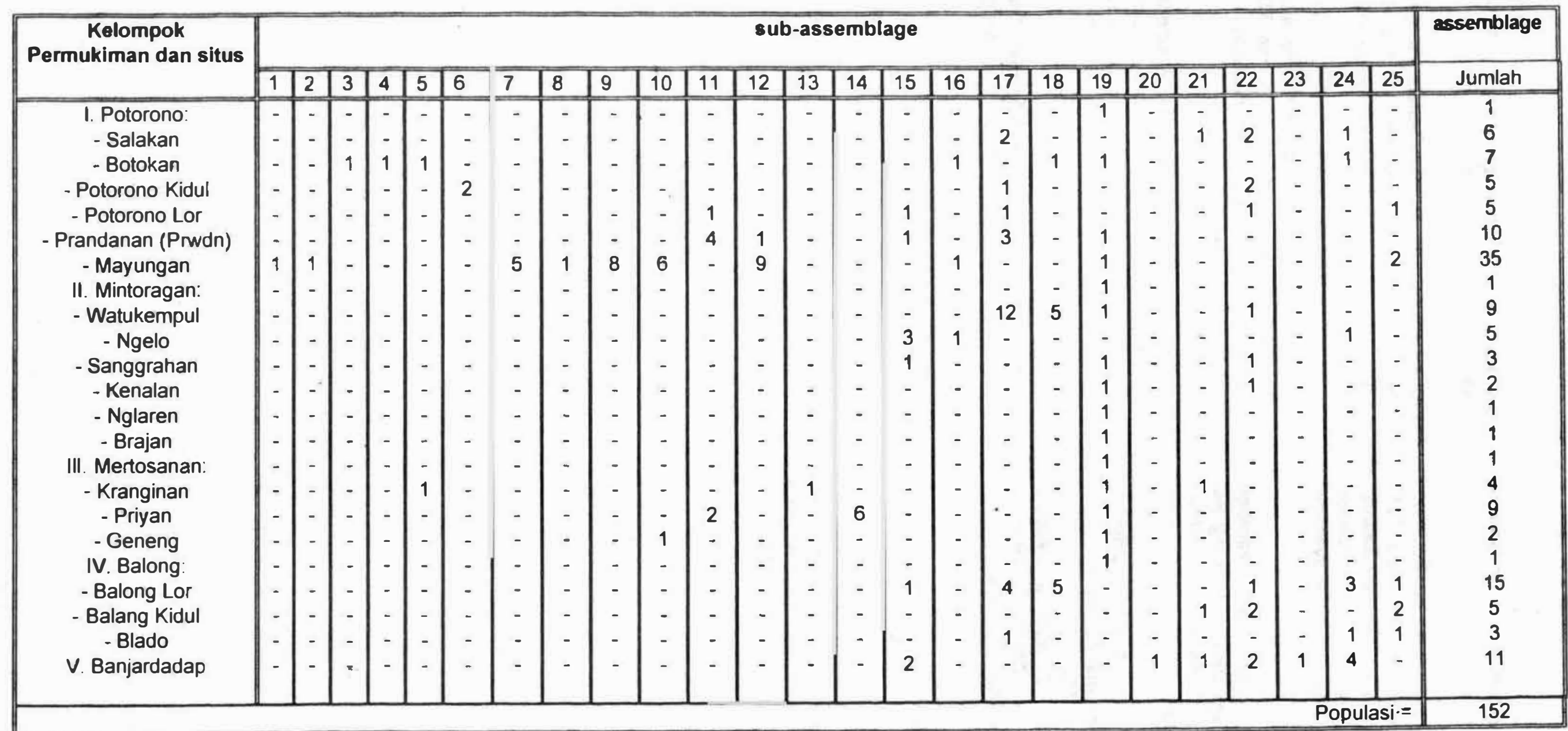

Keterangan nomor dalam kolom tabel :
1. kalamarta
2. kemuncak
3. wadah kotak bertutup dari batu putih
4. lingga
5. yoni
6. batu persegi untuk penyekat
7. batu persegi berlubang 1 tembus
. batu persegi beri

10. batu persegi polos

11. umpak batu persegi polos

12. umpak batu persegi berlubang 1 buntu

13. umpak batu persegi bertonjolan bulat di tengah

14. umpak batu bulat

15. sumur kuna

16. fitur dan struktur bata

17. kuburan kuna

18. inskripsi/epitap
19. toponim
20. fr. ker. enam dinasti
21. fr. ker. dinasti t'ang
22. fr. ker. Sung.
23. fr. ker. Yuan
24. fr. ker. Ming
25. fr. ker. Ch'ing 


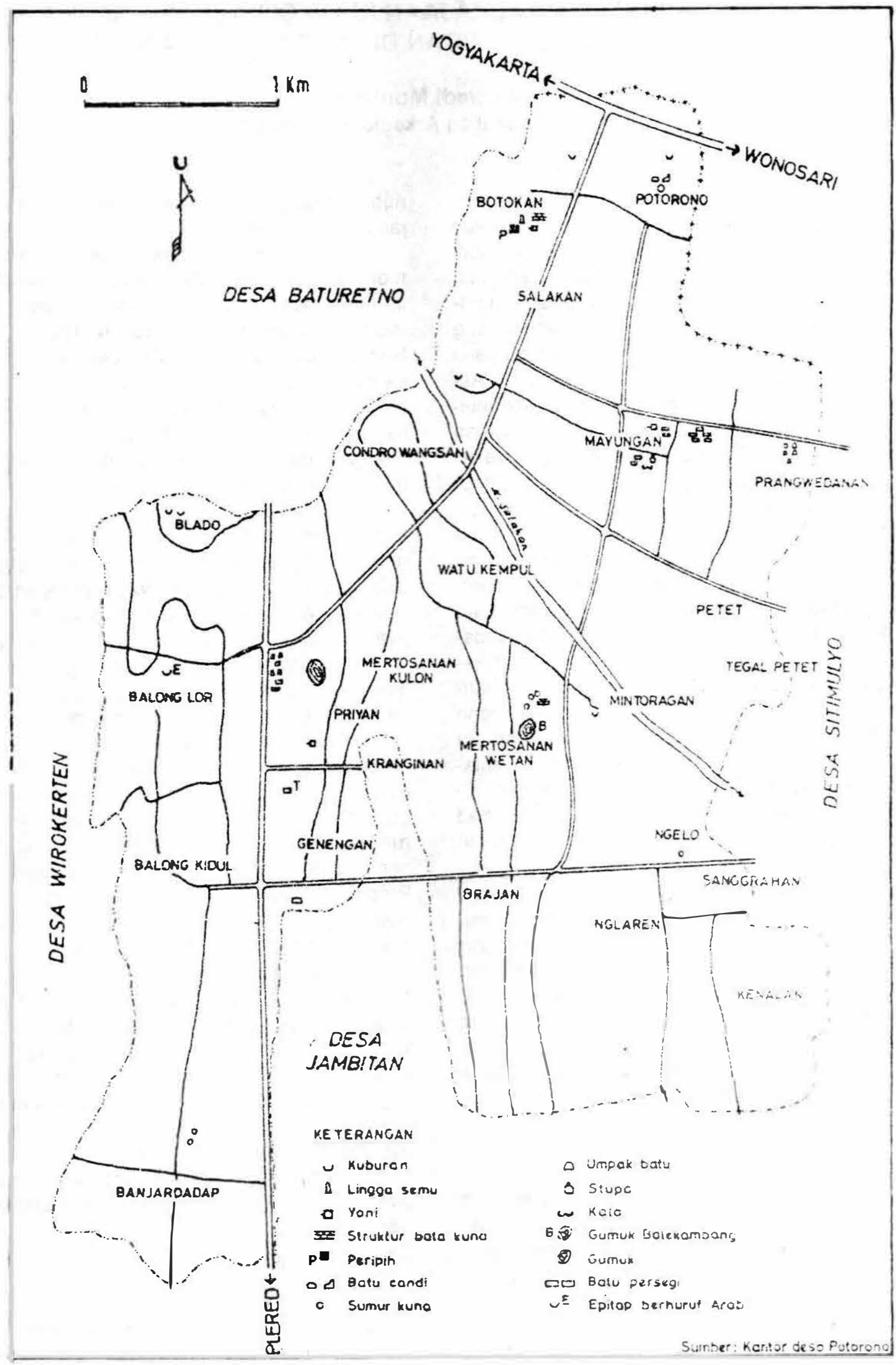

Pela Tata Ruang Permukiman Masa Mataram islam

di Kawasan Situs Potorono, Kecametan Banguntepan, Kcbupaten Gentu!. 